> Gi rask respons på artikler gjennom artikkelens kommentarfelt på tidsskriftet.no. Respons som er postet innen én måned etter at artikkelen er publisert, vurderes for publisering som Brev til redaktøren i papirutgaven.

Redaksjonen forbeholder seg retten til å foreta redaksjonelle endringer.

Forfattere av vitenskapelige artikler har tilsvarsrett, jf. Vancouver-gruppens regler.

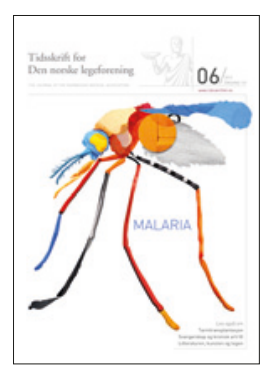

\section{Rådvilt om evidensbaserte råd}

I kommentarartikkelen Hva er evidensbaserte råd? i Tidsskriftet nr. 6/2012 setter Ivar Sønbø Kristiansen prisverdig søkelyset på legers rolle i utvikling av faglige retningslinjer og i utformingen av norsk helsepolitikk (1). Han poengterer også at begrepet «evidens» for sjelden blir definert, blant annet i ferske diskusjoner om overtidige svangerskap og testing for humant papillomvirus. Sønbø Kristiansen reiser viktige spørsmål, men avslører samtidig manglende kjennskap til gjeldende definisjoner av kunnskapsbaserte faglige retningslinjer og egnet metodikk for å lykkes i arbeidet med å utvikle balanserte anbefalinger for diagnostikk og behandling i helsetjenesten $(2,3)$.

Blant utfordringene for dem av oss som lager kunnskapsbaserte faglige retningslinjer, er balansert integrering av systematisk innhentet forskningsbasert kunnskap, erfaringsbasert kunnskap (klinisk ekspertise) og pasientens preferanser/verdier i en gitt kontekst, i tråd med definisjonen på kunnskapsbasert praksis (4). Ledende internasjonale organisasjoner har de siste ti år samlet seg om en felles tilnærming som skal fasilitere systematikk og transparens i vurdering av kvalitet på dokumentasjonen og i prosessen fra dokumentasjon til anbefaling.

GRADE-systemet (Grading of Recommendations Assessment, Development and Evaluation) har en rekke fordeler sammenliknet med tidligere graderingssystemer, blant annet ved entydige definisjoner på kvalitet på dokumentasjonen (tiltro til effektestimatene for pasientviktige utfall) og styrke på anbefalinger (3). Fem faktorer kan svekke kvaliteten på dokumentasjonen: systematiske feil, inkonsistens i resultatene, manglende overførbarhet, upresise effektestimater og publiseringsskjevhet. I prosessen fra dokumentasjon til anbefaling vurderes fire faktorer: balansen mellom ønskede og uønskede konsekvenser av behandling, kvaliteten på dokumentasjonen, verdier og preferanser og ressursbruk.
Vår erfaring med bruk av GRADE i nylig oppdaterte internasjonale retningslinjer for antitrombotisk behandling (5) har medført noen erkjennelser med relevans for fremtidige retningslinjesatsinger:

- Klinikere har genuin klinisk kompetanse, men må også ha tilstrekkelig metodeforståelse og samarbeide med eksperter i forskningsmetodikk og helseøkonomi

- Balansen mellom fordeler og ulemper ved en behandling er ofte hårfin og kan være beheftet med betydelig usikkerhet

- Vi mangler i stor grad pålitelig kunnskap om pasienters verdier og preferanser

De to siste erkjennelsene medfører at de fleste anbefalinger blir såkalt svake/betingede, hvilket fordrer at klinikere skreddersyr appliseringen av anbefalingene til den enkelte pasient. Godt informerte beslutninger hvor også pasienten får muligheten til å vurdere fordeler og ulemper av behandlingen blir dermed stadig viktigere, slik Sønbø Kristiansen argumenterer godt for. Vi oppfordrer Sønbø Kristiansen, norske leger og myndighetene til å sette seg inn i og ta i bruk - denne metodikken, for å slippe unødvendig rådvillhet og svakt funderte anbefalinger i fremtidige retningslinjesatsinger i Norge.

\section{Per Olav Vandvik}

Sykehuset Innlandet Gjøvik

\section{Per Morten Sandset}

Oslo universitetssykehus, Rikshospitalet

Per Olav Vandvik (f. 1968) er dr.med. og førsteamanuensis ved Avdeling for allmennmedisin, Institutt for helse og samfunn, Universitetet

i Oslo. Han er forsker ved Nasjonalt kunnskapssenter for helsetjenesten og konstituert overlege ved Medisinsk avdeling, Sykehuset Innlandet Gjøvik. Vandvik jobber med kunnskapsbaserte faglige retningslinjer internasjonalt (gjennom GRADE working group) og nasjonalt (gjennom Kunnskapssenteret).

Ingen oppgitte interessekonflikter.

Per Morten Sandset (f. 1956) er spesialist i indremedisin/blodsykdommer, med spesialkompetanse i hemostase og trombose. Han er forskningsleder og professor ved Klinikk for kreft, kirurgi og transplantasjon ved Oslo universitetssykehus, editor-in-chief for Thrombosis Research og generalsekretær for European Thrombosis Research Organization. Ingen oppgitte interessekonflikter.
Litteratur

. Kristiansen IS. Hva er evidensbaserte råd? Tidsskr Nor Legeforen 2012; 132: 638-9.

2. Standards for developing trustworthy clinical practice guidelines. www.iom.edu/Reports/2011/ Clinical-Practice-Guidelines-We-Can-Trust/ Standards.aspx (16.4.2012).

3. GRADE working group. www.gradeworkinggroup. org/society/index.htm (16.4.2012).

4. Vandvik PO, Eiring $\emptyset$. Kunnskapsbasert praksis for norske leger? Tidsskr Nor Legeforen 2011; 131 : 1755.

5. Guyatt GH, Norris SL, Schulman S et al. Methodology for the development of antithrombotic therapy and prevention of thrombosis guidelines: Antithrombotic Therapy and Prevention of Thrombosis, 9th ed: American College of Chest Physicians Evidence-Based Clinical Practice Guidelines. Chest 2012; 141 (suppl): 53S-70S.

\section{Ufornuftig om evidens}

I en kommentarartikkel i Tidsskriftet nr. 6/2012 kommer professor Ivar Sønbø Kristiansen med noen betraktninger om evidensbasert medisin (1). Han bruker debatten om hvilken HPV-test som er best egnet i sekundærscreening mot livmorhalskreft som eksempel (2). Sønbø Kristiansen er misfornøyd med at Helsedirektoratet har fjernet refusjonen for en norskutviklet RNAtest. Han har dårlige argumenter. Både nasjonalt og internasjonalt anbefales test med høy sensitivitet (>98\%) som tester for minst 12 HPV-typer, ikke bare fem typer (sensitivitet 53-74\%), som den norske testen (3).

Sønbø Kristiansen påstår at Helsedirektoratets avgjørelse er tatt på bakgrunn av Kreftregisterets evaluering. Det er feil. Den er tatt på bakgrunn av internasjonal vitenskapelig litteratur. Avgjørelsen om fjerning av takstrefusjon for den norske testen ble utsatt pga. innsigelser fra den kommersielle aktøren og en liten støttegruppe, heri inkludert Sønbø Kristiansen. Kreftregisterets evaluering viste at den norske testen var for dårlig, i tråd med internasjonal litteratur (3).

Sønbø Kristiansen hevder at fem av seks kvinner som får utført konisering ikke ville ha utviklet kreft. Han mener kvinner ville gjøre ulike avveininger i forhold til om konisering skal utføres eller ikke - «... noen kan velge å ta en liten kreftrisiko for å unngå falskt positive prøver eller redusert fertilitet». Vi synes han er på ville veier. Hans estimat er for lavt. Trolig ville mellom 500 og 1000 av de 3000 kvinnene som årlig koniseres i Norge etter kolposkopi og biopsi utvikle kreft om de avsto fra konisering (4). Vi tror ikke kvinner vil oppfatte dette som en «liten kreftrisiko».

Sønbø Kristiansen skriver at det finnes to grupper forskere: De som er for RNA-tester 
og de som er for DNA-tester. Han forstår ikke poenget. Spørsmålet dreier seg ikke om RNA- eller DNA-test, men om hvor mange HPV-typer det testes for. Det må testes for minst 12 typer, og det finnes RNA-tester som gjør dette med akseptabel sensitivitet. Hvorfor denne forkjærligheten for en norsk RNA-test når det er andre veldokumenterte RNA-tester med akseptabel sensitivitet?

Det er bra denne saken er løst etter årelang strid. Evidensbasert kunnskap kan ikke lenger tilsidesettes av kommersielle/politiske krefter. Statens helsetilsyn har nå bedt om en granskning $i$ alle helseforetak som ikke har brukt adekvat test, slik at man forsikrer seg om at ingen kvinner er fulgt for dårlig opp etter negativ HPV-test.

\section{Pål Øian \\ Ole-Erik Iversen \\ Knut Hordnes \\ Bjørn Backe \\ Tromsø, Bergen, Trondheim}

Pål Øian (f. 1948) er spesialist i fødselshjelp og kvinnesykdommer. Han er avdelingsoverlege/ professor ved Kvinneklinikken ved Universitetssykehuset Nord-Norge og medlem av kvalitetsutvalget i Norsk gynekologisk forening. Ingen oppgitte interessekonflikter.

Ole Erik Iversen (f. 1945) er overlege ved Kvinneklinikken, Haukeland universitetssykehus, og professor ved Institutt for klinisk medisin, Universitetet i Bergen. Han er medlem i styringsgruppen for masseundersøkelsen mot livmorhalskreft.

Ingen oppgitte interessekonflikter.

Knut Hordnes (f. 1959) er spesialist i fødselshjelp og kvinnesykdommer og arbeider ved Hospitalet Betanien i Bergen. Han er leder av Norsk gynekologisk forening og medlem av faglig rådgivningsgruppe for masseundersøkelsen mot livmorhalskreft.

Ingen oppgitte interessekonflikter.

Bjørn Backe (f. 1947) er seksjonsoverlege professor dr.med. ved Fødeavdelingen, Kvinneklinikken, St. Olavs hospital/Norges teknisknaturvitenskapelige universitet. Han er tidligere leder Norsk gynekologisk forening. Ingen oppgitte interessekonflikter.

\section{Litteratur}

1. Kristiansen IS. Hva er evidensbaserte råd? Tidsskr Nor Legeforen 2012: 132: 638-9.

2. Øian P, Iversen OE, Hordnes K et al. Mer evidens og mindre politikk, takk! Tidsskr Nor Legeforen 2011; 131: 2346

3. Haldorsen T Skare GB, Bjørge T. Sekundærscreening med HPV-tester i Masseunders økelsen mot livmorhalskreft. Oslo: Kreftregisteret, 2011.

4. McCredie MR, Sharples KJ, Paul C et al. Natural history of cervical neoplasia and risk of invasive cancer in women with cervical intraepithelial neoplasia 3: a retrospective cohort study. Lancet Oncol 2008; 9: 425-34

\section{Lege, student og medmenneske}

I det siste har vi vært vitne til flere til dels rystende fortellinger fra medisinstudenter om problematiske opplevelser i klinisk praksis. Det dreier seg om hvordan studenter og pasienter opplever krenkelser i undervisnings- og samhandlingssituasjoner. Dette skal ikke skje - det dreier seg om dårlige holdninger, mangel på medmenneskelighet og manglende respekt for syke mennesker.

Dette er situasjoner der verken studenten, involverte sykepleiere eller andre legekolleger tør si ifra. I tillegg kommer historier fra undervisningssituasjoner i den teoretiske delen av medisinstudiet der studenter kan føle seg latterliggjort, ikke tør stille viktige spørsmål eller er redde for å si ifra fordi de frykter negative konsekvenser. Ikke alle disse historiene er like representative, men det er likevel nok av dem til at man må ta dem alvorlig. Man skal ha en læringskultur der det oppfordres til åpenhet og kritikk. Man skal kultivere en legerolle der medmenneskelighet er kjennetegnet ved legen så vel som underviseren. Allikevel hører vi studenter som finner seg i verbal trakassering, fordi «Vi må tåle det, vi skal jo bli leger».

I Tidsskriftets påskenummer beskriver medisinstudent Ingrid Neteland en læringskultur som fratar studenten all selvtillit (1). Tidligere studiedekan i Oslo Per Brodal svarer henne (2). Vi er redd Brodal ikke går langt nok når han setter søkelys på den kliniske undervisningen alene. Vi tror problemet med mangel på respekt for studentene og mangel på medmenneskelighet i veiledningen også strekker seg til undervisningen $i$ teori og basalfag, og vi er redd at dette er mer et strukturelt problem enn bare enkeltstående hendelser. Hva må gjøres?

For det første trenger vi mer systematisk kunnskap om læringsmiljøet i både den kliniske og den teoretiske delen av medisinstudiet. Når det gjelder undervisning i etikk og kommunikasjon og forskning på læring og dannelse, bør etikk- og atferdsfagdelen av undervisningen spille på lag med den kliniske undervisningen i større grad enn det gjør i dag.

For det andre må man legge mer vekt på legen som forbilde og rollemodell - ikke bare i kraft av omfattende kunnskaper, men også ut fra legens og underviserens holdninger, moralske ansvar og etiske dømmekraft. Medisinstudiet vektlegger objektiv og systematisk kunnskap om behandling, diagnostikk og prognostikk, noe som gjør at man lett glemmer viktigheten av kunnskap om hvordan det er å være pasient eller pårørende - eller student, for den slags skyld. Det er heller ikke tilstrekkelig med mer øvelse i og kunnskaper om kommunikasjon og pedagogikk hvis ikke slik kunnskap forankres i den enkeltes personlighet og dannelse.

Til slutt: Det er viktig å utvikle gode eva- lueringssystemer som fanger opp resultater av ulike lærings- og veiledningsformer og studentenes faglige og etiske modning i løpet av medisinstudiet.

\section{Per Nortvedt \\ Reidar Pedersen}

Jan Helge Solbakk

Senter for medisinsk etikk

Universitetet i Oslo

Per Nortvedt (f. 1952) er professor og leder for Senter for medisinsk etikk, Universitetet i Oslo. Han er også undervisningsleder for fagområdet medisinsk etikk ved medisinstudiet i Oslo.

Ingen oppgitte interessekonflikter.

Reidar Pedersen (f. 1973) er utdannet lege og filosof. Han er forsker (med professorkompetansel ved Senter for medisinsk etikk, Universitetet i Oslo, og jobber med etikk og kommunikasjon i helsetjenesten.

Ingen oppgitte interessekonflikter.

Jan Helge Solbakk (f. 1956) er utdannet lege og teolog og har en doktorgrad i antikkens filosofi. Han er professor i medisinsk etikk ved Senter for medisinsk etikk, Universitetet i Oslo, og arbeider for tiden med et prosjekt, Biolpolethics, som benytter teater, opera og film i etikkundervisningen.

Ingen oppgitte interessekonflikter.

\section{Litteratur}

1. Neteland I. Medisinsk lettvekter - bare meg? Tids skr Nor Legeforen 2012; 132: 696-7.

. Brodal P. Et varselrop om læringsmiliøet i klinikken. Tidsskr Nor Legeforen 2012; 132: 698

\section{U-land og vi-land}

Knut Wester konstaterer i Tidsskriftet nr. 6/2012 at medisinsk sett blir gapet mellom oss og utviklingslandene stadig større (1). Han spør om vår ressursbruk påvirker helsetilbudet i u-landene. Det er vanskelig å gi noe enkelt og entydig svar. Det kan hevdes at vår frontlinjemedisin før eller siden vil komme alle til gode. Men dette er hypotetisk. Fenomenet «hjerneflukt» er derimot en realitet. U-landene tappes for menneskelige ressurser når både de dyktigste og de nest dyktigste av faglige og økonomiske grunner forlater et haltende helsevesen.

Vi kan selvsagt ikke vurdere spørsmål som dette uten å trekke inn etiske kvaliteter som solidaritet, anstendighet, ansvar og plikt. Solidaritet har å gjøre med opplevelsen av å være i samme båt, selv om noen seiler på første klasse, enn så lenge. Wester skriver om barn som før i tiden fikk beskjed om å spise opp maten sin fordi det var barn i Afrika som sultet. Dette er det gamle nøysomhetsidealet, som er blitt oss fjernt. Vi kan trekke på smilebåndet, men i bunn og 